Article

\title{
Spatial Analysis of the Chemical Regime of Groundwater in the Karatal Irrigation Massif in South-Eastern Kazakhstan
}

\author{
Dinara B. Barmakova ${ }^{1}$, Javier Rodrigo-Ilarri ${ }^{2, * \mathbb{D}}$, Vyacheslav A. Zavaley ${ }^{1}$, María-Elena Rodrigo-Clavero ${ }^{2} \mathbb{D}$ \\ and José E. Capilla ${ }^{2}$
}

check for

updates

Citation: Barmakova, D.B.;

Rodrigo-Ilarri, J.; Zavaley, V.A.; Rodrigo-Clavero, M.-E.; Capilla, J.E. Spatial Analysis of the Chemical Regime of Groundwater in the Karatal Irrigation Massif in South-Eastern Kazakhstan. Water 2022, 14, 285. https://doi.org/ $10.3390 /$ w14030285

Academic Editors: Francesco Sdao and Filomena Canora

Received: 24 November 2021

Accepted: 15 January 2022

Published: 19 January 2022

Publisher's Note: MDPI stays neutral with regard to jurisdictional claims in published maps and institutional affiliations.

Copyright: (C) 2022 by the authors. Licensee MDPI, Basel, Switzerland. This article is an open access article distributed under the terms and conditions of the Creative Commons Attribution (CC BY) license (https:// creativecommons.org/licenses/by/ $4.0 /)$.
1 Department of Hydrogeology, Engineering and Oil and Gas Geology, Geology and Oil-Gas Business Institute named after K. Turyssov. Satbayev University, 22a Satpaev St., Almaty 050013, Kazakhstan; d.barmakova@stud.satbayev.university (D.B.B.); v_zavaley@mail.ru (V.A.Z.)

2 Instituto de Ingeniería del Agua y del Medio Ambiente (IIAMA), Universitat Politècnica de València (UPV), Camino de Vera s/n, 46022 Valencia, Spain; marodcla@upv.es (M.-E.R.-C.); jcapilla@upv.es (J.E.C.)

* Correspondence: jrodrigo@upv.es

\begin{abstract}
Understanding the groundwater chemical regime on irrigated lands is relevant for assessing hydrogeological and reclamation processes. Water chemistry, natural and climatic conditions, and drainage characteristics define the complex hydrochemical connections which are formed between irrigation waters, soil, and water of the unsaturated zone and groundwater. This research paper presents the results of studies of seasonal changes in the chemical composition of groundwater in the Karatal irrigated massif. A detailed analysis of the salt regime and chemical composition of groundwater have been performed based on a large number of samples for 2019. Besides, data related to the Karatal River and drainage waters quality inside the basin have also been analyzed. Results demonstrate that the salinization processes in the massif are determined by hydrogeological conditions and drainage availability. In the north-eastern part of the massif, a high risk of soil salinization has been observed as a consequence of all the salinization processes which are determined by its hydrogeological conditions and drainage availability. Data analysis over soil samples and irrigation and drainage waters show that the hydrochemical regime of groundwater on Karatal irrigation massif is influenced by the presence of saline soil-forming rocks, the groundwater depth, the volume, and the quality of irrigation waters, the characteristics of the natural drainage, and evaporation processes.
\end{abstract}

Keywords: groundwater; irrigated land; salinity; chemical composition

\section{Introduction}

Increasing salt concentrations is one of the most common environmental and reclamation problems in irrigated agriculture [1-3]. Due to the variability of water management and economic conditions on irrigation systems, groundwater levels and geochemistry transformations occur [4]. These changes have an impact on the reclamation state, which determines the productivity of the irrigated lands. The knowledge of the groundwater chemical regime is critical for assessing the reclamation status of irrigated land. Groundwater chemical composition depends on: (i) the irrigation water quality; (ii) the water supply volume; (iii) the climatic and hydrogeological conditions; (iv) the lithological composition of the aeration zone and (v) the drainage characteristics of the territory [5-9].

Hydrogeological conditions play an important role in the formation of all processes of salt and water exchange on irrigated lands. Some recent studies describe that irrigation with superficial water induces a salinity increase in groundwater $[10,11]$. However, other studies show that this type of irrigation reduces the salinization impacts over the aquifer [12,13]. So, groundwater levels and soil geochemistry are closely interrelated with the soil cover characteristics and the irrigation conditions. Despite water resources being very limited 
in arid regions, groundwater quality is determined by its interaction with rocks and soil profiles [14].

Groundwater, depending on its depth and degree of mineralization, drainage conditions, lithological features, and other factors, represents the main source of salinization of the upper soil cover. Therefore, the study of the groundwater regime on irrigated lands, the identification of all factors influencing them, the determination of the conditions of formation by type of regime, and the spatial boundaries of the impact should be given important importance [15-17]. Based on these data, it is possible to predict changes in hydrogeological and meliorative conditions, develop projects to improve the condition of irrigated lands, and engineering and ecological reconstruction of irrigation systems.

Monitoring of irrigated lands is a system of stationary observations of the reclamation condition of irrigated lands, carried out in order to timely identify changes occurring on them, assess and make recommendations for improving and rational use of irrigated lands. Efficient and well-managed irrigation water practice including quantifying the groundwater table depth and monitoring water quality is of utmost importance for decisionmakers, growers, and experts [18]. Indicators of the reclamation state of irrigated lands are: (i) hydrogeological conditions (level, mineralization, and chemical composition of groundwater); (ii) salinity and degree of salinity of soils; (iii) engineering and geological processes (subsidence, overexposure, irrigation erosion).

Monitoring irrigated lands allow assessing and forecasting their reclamation conditions, identifying the causes of their deterioration as well as changes in the territories in the zone of direct influence of irrigation.

The reclamation state of irrigated lands determines the state of the system: soils, soils of the aeration zone, groundwater formed as a result of soil development, hydrogeological and engineering-geological processes under the influence of various reclamation measures and characterizing the degree of suitability of land for agricultural production [16]. The content of chemical elements such as $\mathrm{Cl}, \mathrm{Na}$, as well as $\mathrm{pH}$ and mineralization indicators do not affect the use of land at certain stages but can affect the productivity of land [19-21]. Lime can be used to increase soil $\mathrm{pH}$, reducing trace element mobility and bioavailability (like $\mathrm{Cd}, \mathrm{Co}, \mathrm{Cu}, \mathrm{Ni}, \mathrm{Pb}, \mathrm{Sb}$, and $\mathrm{Zn}$ ) due to enhanced adsorption and/or precipitation [22]. Liming enhances the physical, chemical, and biological properties of soil through its direct effect on the amelioration of soil acidity and its indirect effect on the mobilization of some of the major and trace element nutrients, immobilization of toxic metals, and improvements in soil structure and hydraulic conductivity [23].

The impact of agricultural practices on water quality has always been studied primarily with an emphasis on surface waters. Groundwater is more difficult to study. However, the impact on ground and surface waters is equally important. In non-irrigated areas, agriculture often leads to an increase in recharge, which sometimes leads to the leaching of salts from the unsaturated zone into groundwater. In irrigated areas, groundwater salinization may be the result of salty water irrigation, salt movement down in an unsaturated zone of salt dissolution, as well as salt accumulation due to water uptake by plants.

The processes of redistribution of elements occur in the soil aeration zone. Rising groundwater levels and salinity are considered to be the main cause of secondary salinization of irrigated lands [24,25]. To date, 210,400 hectares of the Almaty region in Kazakhstan are saline to varying degrees which is $36 \%$ of the available irrigated area. The deterioration of the reclamation status of rice irrigation systems as a result of changes in irrigation and economic conditions is a matter of great concern [26-28]. Methods for monitoring the groundwater quality parameters and chemical element immigration are effective if there is a high-quality source and regularly updated material in the database $[19,29]$. The use of spatial analysis techniques significantly simplified the assessment of the hydrogeological and reclamation state [30]. Groundwater studies are used to analyze site suitability, manage available data and resources, assess soil vulnerability to salinization, model groundwater runoff, solute transport, and leaching [31,32]. The results of this analysis are necessary for creating systems to support spatial solutions using GIS $[33,34]$. Thus, in order to identify 
the salinity distribution area, mapping of surface and groundwater quality was required. The quality of groundwater depends on the evolution over time of various parameters, such as $\mathrm{pH}$, salinity, $\mathrm{Ca}, \mathrm{Mg}$, or $\mathrm{Cl}$ [35]. The map is often compiled using the inverse distance weighting (IDW) method. Much of the research and development related to Earth sciences has been done using spatial technologies. GIS software is an effective tool in mapping the chemical composition of groundwater and is important for monitoring and managing hydrogeological and reclamation processes $[19,29,33,36]$.

Under this working scope, the objective of this research is to describe and understand the chemical regime of groundwater in the Karatal irrigation massif.

\section{Materials and Methods}

\subsection{Description of the Study Area}

The study area is located on the territory of the Karatal district of the Almaty region of the Republic of Kazakhstan ( $77^{\circ} 53^{\prime} 17^{\prime \prime}$ east longitude and $45^{\circ} 23^{\prime} 26^{\prime \prime}$ north latitude, $78^{\circ} 00^{\prime} 40^{\prime \prime}$ east longitude and $45^{\circ} 06^{\prime} 46^{\prime \prime}$ north latitude). The irrigation system is located in the Karatal River valley, in the eastern marginal part of the South Balkhash depression. The massif stretches along the Karatal River for $20 \mathrm{~km}$ and is about $12 \mathrm{~km}$ wide (Figure 1).

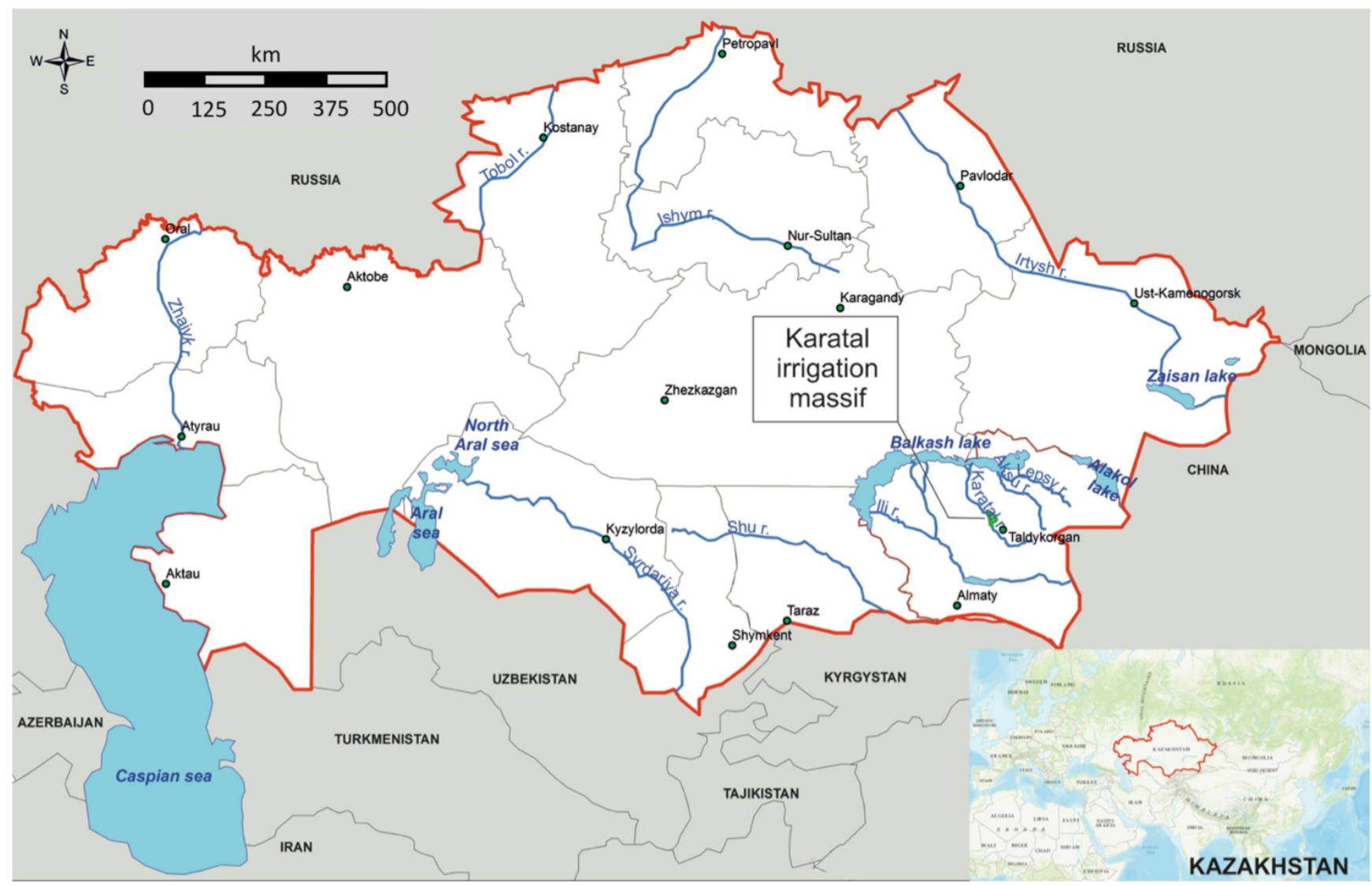

Figure 1. Location of the Karatal irrigation massif inside the Republic of Kazakhstan.

The climate in the study area is sharply continental, characterized by severe winters, hot summers, and short springs and autumns. In 2019, the climatic conditions of the region during the growing season were characterized by a dry and hot summer. The maximum average monthly air temperature was observed in July $\left(26.9^{\circ} \mathrm{C}\right)$. The coldest month was December $\left(-9.3^{\circ} \mathrm{C}\right)$. The sum of active temperatures (the sum of the average daily air temperatures above $+15^{\circ} \mathrm{C}$ ) for the period May-August was $2755^{\circ} \mathrm{C}$.

The total area of irrigated land was 11,845 ha. The terrain is calm, the slope does not exceed $0.001 \mathrm{~m} / \mathrm{m}$ and decreases in a north-westerly direction. The absolute elevation of the 
terrain surface varies from 435 to $417 \mathrm{~m}$. Soils are characterized as light chestnut gray soils, composed mainly of sandy loam, slightly saline. Soda-sulfate by anions, calcium-sodium by cations type of salinity chemistry is common in the eastern and northeastern parts of the massif. Here, the salt content in the soil horizon is higher than $0.6 \%$. In the area of the PR-35 system (well 246), soils with chloride-sulfate magnesium-sodium with a salt content of $0.6 \%$ were identified. Well 179 is located on lands with sulfate sodium-calcium chemistry, where the salt content reaches $0.6 \%$. In the northern and southeastern parts of the massif, soils are salted with medium sulfate by anions and a type of chemistry mixed by cations. On these soils, salt content varies from 0.3 to $0.5 \%$.

On the territory of the massif, underlying rocks are alluvial deposits of the Quaternary age, represented by alternating layers of loam, sand, and sandy loam. The thickness of the cover deposits varies from 0.5 to $6 \mathrm{~m}$ and filtration coefficients from 0.02 to $0.3 \mathrm{~m} /$ day. The water-bearing rocks of the upper water-saturated stratum include sandy loam, loam, powdery and clay fine-grained sands, and lower-gravel-pebbles with sandy or sandy loam aggregates.

Land use has significantly changed in recent years due to market demands, subsidies, etc. The irrigated area is used entirely for agricultural crops. The water management conditions of the district, due to the physical wear and tear of irrigation channels and structures and the insufficient volume of repair and restoration work, are characterized as unsatisfactory. For these reasons, the destruction of the main structures of the structures, siltation, and overgrowth of weeds of the channels occur. The existing on-farm irrigation and collector-drainage channels are unattended and repair work is practically not carried out on them. All this leads to violations of the operating conditions of the irrigation system.

The research work described below was carried out in 2019 and included (i) observations of the chemical regime of groundwater in fields with rice crops and dry crops; (ii) determining the location of areas with the spread of brackish groundwater and (iii) determining the water quality in the Karatal River at the site of water intake and after mixing with collector and drainage waters.

\subsection{Data Collection}

Observations of the mineralization and chemical composition of groundwater were carried out by sampling water from $10 \mathrm{~m}$ deep observation wells following the requirements established by the monitoring rules of evaluation of irrigated lands in force at the Republic oz Kazakhstan [37]. The data collection process on the irrigated lands of the Karatal massif was done by the Zonal Hydrogeological and Reclamation Center of the Ministry of Agriculture of the Republic of Kazakhstan.

This process was done two times, in spring and autumn of 2019. Groundwater samples were taken from the existing 62 observation wells, irrigation wells located at the entrance to the massif in its southern part, and at the discharge point of the idle K-4 collector in the northern part (Figure 2).

Supplementary Materials are provided showing the available data for each one of the 62 sampling sites. This information includes:

(i). Sampling site name

(ii). Sampling date

(iii). $\mathrm{pH}$

(iv). Values of the following parameters $\left(\mathrm{mg} / \mathrm{dm}^{3}\right)$ : $\mathrm{CO}_{3}, \mathrm{H} \mathrm{CO}_{3}, \mathrm{Cl}, \mathrm{SO}_{4}, \mathrm{Ca}, \mathrm{Mg}, \mathrm{Na}+\mathrm{K}$, Salinity

(v). Kurlov's formula (as required by [37])

(vi). Sodium adsorption ratio (SAR) 


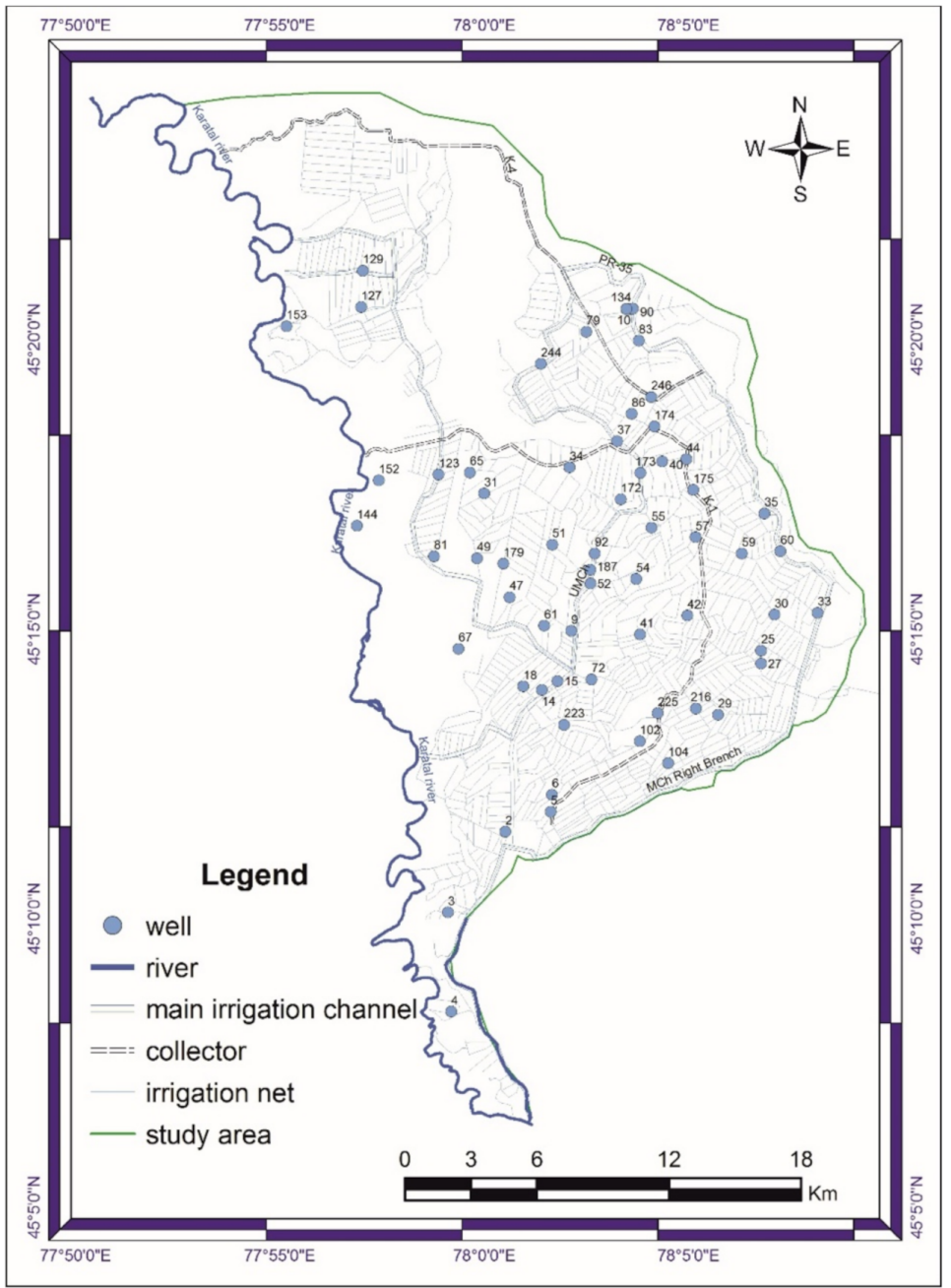

Figure 2. Scheme of the Karatal irrigation system.

\subsection{Data Analysis}

Groundwater quality has been assessed by analyzing its degree of mineralization and chemical composition. Chemical composition was determined by the content of anions in the samples: $\mathrm{HCO}_{3}, \mathrm{SO}_{4}, \mathrm{Cl}$, and cations- $\mathrm{Ca}, \mathrm{Mg}, \mathrm{Na}, \mathrm{K}$, which are expressed in $\mathrm{mg} / \mathrm{dm}^{3}$ or $\mathrm{mg}$ /eq. The sum of anions and cations determines the salinity. According to the degree of salinity, groundwater is classified into fresh (salt concentration up to $1 \mathrm{~g} / \mathrm{dm}^{3}$ ), slightly salty (1-3), strongly salty (3-5), salty (5-50), and brines (>50). The chemical composition and mineralization of water are expressed by Kurlov's equations (see Supplementary Materials). According to this formula, the chemical type of water is determined by the predominant anions and cations. The type of water is set at the beginning according to the content of anions, and then cations in descending order. If the content of components is less than $10 \%$, they do not participate in determining the type of water [37].

There are two main groups in surface and underground waters: macro- and microcomponents. Macro components are determined by the predominant cations and anions. Their content in water determines the amount of dry residue, specific gravity, and the nature of the physical properties of water. For the general characteristics of the composition and properties of water, an abbreviated chemical analysis of water has been performed.

When conducting water laboratory tests, the requirements for the types of analyses performed and the applicable regulatory documents are observed. The types of analyses and current standards for determining the chemical composition of natural waters in the Republic of Kazakhstan are shown in Table 1. 
Table 1. Types of analyses and current standards for determining the chemical composition of natural waters (surface and groundwater) in the Republic of Kazakhstan.

\begin{tabular}{|c|c|}
\hline Types of Analyses & Current Kazakh State Standard \\
\hline $\begin{array}{l}\text { Abbreviated chemical analysis }\left(\mathrm{pH}, \mathrm{Cl}^{-},\right. \\
\mathrm{SO}_{4}{ }^{2-}, \mathrm{HCO}_{3}{ }^{-}, \mathrm{NO}_{3}-, \mathrm{CO}_{3}{ }^{2-}, \mathrm{Ca}^{2+}, \mathrm{Mg}^{2+}, \\
\left.\mathrm{Na}^{+}, \mathrm{K}^{+}, \mathrm{CO}_{3}{ }^{2-}, \mathrm{H}_{2} \mathrm{CO}_{3}\right)\end{array}$ & \\
\hline Sodium ion $\left(\mathrm{Na}^{+}\right)$ & GOST 26449.1-85, i. 7. \\
\hline Calcium ion $\left(\mathrm{Ca}^{2+}\right)$ and Magnesium ion $\left(\mathrm{Mg}^{2+}\right)$ & GOST 26449.1-85, i. 11. \\
\hline Potassium ion $\left(\mathrm{K}^{+}\right)$ & GOST 26449.1-85, i. 12. \\
\hline Sulfate ion $\left(\mathrm{SO}_{4}{ }^{2-}\right)$ & GOST 26449.1-85, i. 9. \\
\hline Chlorine ion $\left(\mathrm{Cl}^{-}\right)$ & GOST 26449.1-85, i. 13. \\
\hline Bicarbonate $\left(\mathrm{HCO}_{3}{ }^{-}\right)$ & GOST 26449.1-85, i. 18. \\
\hline Alkalinity $\mathrm{pH}$ & GOST 26449.1-85, i. 17. \\
\hline
\end{tabular}

The value of the Sodium adsorption ratio (SAR) of groundwater to evaluate the possible salinization of soil in contact with these waters was calculated according to:

$$
\mathrm{SAR}=\frac{1.41 \mathrm{Na}}{\sqrt{\mathrm{Ca}+\mathrm{Mg}}}
$$

The assessment of water quality by the SAR value is given in Table 2 .

Table 2. Assessment of water quality by SAR value.

\begin{tabular}{cccccc}
\hline \multirow{2}{*}{$\begin{array}{c}\text { Total Water Salinity } \\
\left(\mathbf{g} / \mathbf{d m}^{\mathbf{3}}\right)\end{array}$} & \multirow{2}{*}{$\begin{array}{c}\text { Hazard } \\
\text { of Soil Salinization }\end{array}$} & Low & Average & High & Very High \\
\cline { 3 - 6 } & Low & $8-10$ & $15-18$ & $22-26$ & $>26$ \\
$<1$ & Average & $6-8$ & $12-15$ & $18-22$ & $>22$ \\
$1-2$ & High & $4-6$ & $9-12$ & $14-18$ & $>18$ \\
$2-3$ & Very high & $2-4$ & $6-9$ & $11-14$ & $>14$ \\
\hline 3 & & & & &
\end{tabular}

Due to the large number of variables, the data analysis was based on a geostatistical analysis method. Results of the water analysis were processed and interpreted through cartographic methods. Spatial maps of $\mathrm{pH}, \mathrm{SAR}$, and mineralization, as well as maps of the concentration distributions of each ion in groundwater, were obtained using the IDW interpolation method implemented inside the ArcGIS software. This interpolation method is based on the assumption that the values that are closer to each other are more similar than those that are located further away. The measured values surrounding the unmeasured location were used for prediction. As mentioned above, mapping helped to understand field information but it was not enough to take into account all the influencing factors. Once data were displayed on a map a quantitative study was performed to establish correlations between the parameters leading to a better understanding of the chemical regime of groundwater in the study area. The zonal statistical tool was used for calculating areas with different groundwater mineralization and calculations were made according to the accepted gradation. Previously, it was necessary to apply a layer of farm boundaries on the constructed map, within which the spatial calculation of the area should be made. The Spatial Analyst tools were the main ones used in creating the maps. Therefore, spatially integrated data and analytical tools were used to assess the hydrogeological and reclamation status of irrigated land. Results obtained from the analysis were compared with the actual Kazakh normative data of monitoring irrigated lands.

\section{Results and Discussion}

The generated spatial and attribute databases are integrated to create maps of spatial variations of the main chemical parameters. Groundwater quality maps are shown in the figures below to visualize the spatial distribution of maximum ion concentrations. 
The generation of groundwater quality maps helps to understand the current state of groundwater in the area and to assess the hydrochemical regime as well as to visualize the trend of salt accumulation processes [38].

\subsection{Surface Water Quality}

Results of laboratory analyses show that the water used for irrigation of agricultural crops is fresh and suitable for irrigation. During the growing season, the salinity of irrigation water varied up to $424 \mathrm{mg} / \mathrm{dm}^{3}$. The chemical composition of these waters is bicarbonate-sulfate sodium-calcium. The SAR index did not exceed 3.4, which indicates a low risk of soil salinization.

The salinity of the Karatal River water after mixing with the K-1 collector-drainage waters varied from $293 \mathrm{mg} / \mathrm{dm}^{3}$ to $424 \mathrm{mg} / \mathrm{dm}^{3}$ during the entire vegetation period. It should be noted that the collector-drainage waters currently entering the river do not lead to a deterioration in the quality of the river water.

The salinity of reservoir and drainage waters in the $\mathrm{K}-1$ reservoir at the beginning of the growing season varied from $711 \mathrm{mg} / \mathrm{dm}^{3}$ to $725 \mathrm{mg} / \mathrm{dm}^{3}$. In August, the mineralization decreased to $677 \mathrm{mg} / \mathrm{dm}^{3}$. After the water supply was stopped in September, the salt content in the collector-drainage waters decreased to $429 \mathrm{mg} / \mathrm{dm}^{3}$, and in October, when the intensive removal of salts from the soils of the aeration zone occurred with a decrease in the groundwater levels, the salinity of the collector-drainage waters reached $1370 \mathrm{mg} / \mathrm{dm}^{3}$. The chemical composition of the water is bicarbonate-sulfate calcium-sodium. The SAR index did not exceed 8.0 during the entire observation period.

Figure 3 shows the dynamics of salinity of the irrigation and collector-drainage waters and the average salinity of groundwater over a five-year period. The calculation did not take into account samples of wells $86,174,175,179$ which are located in areas with saline soils and insufficiently provided with drainage in the north-eastern and central parts of the massif.

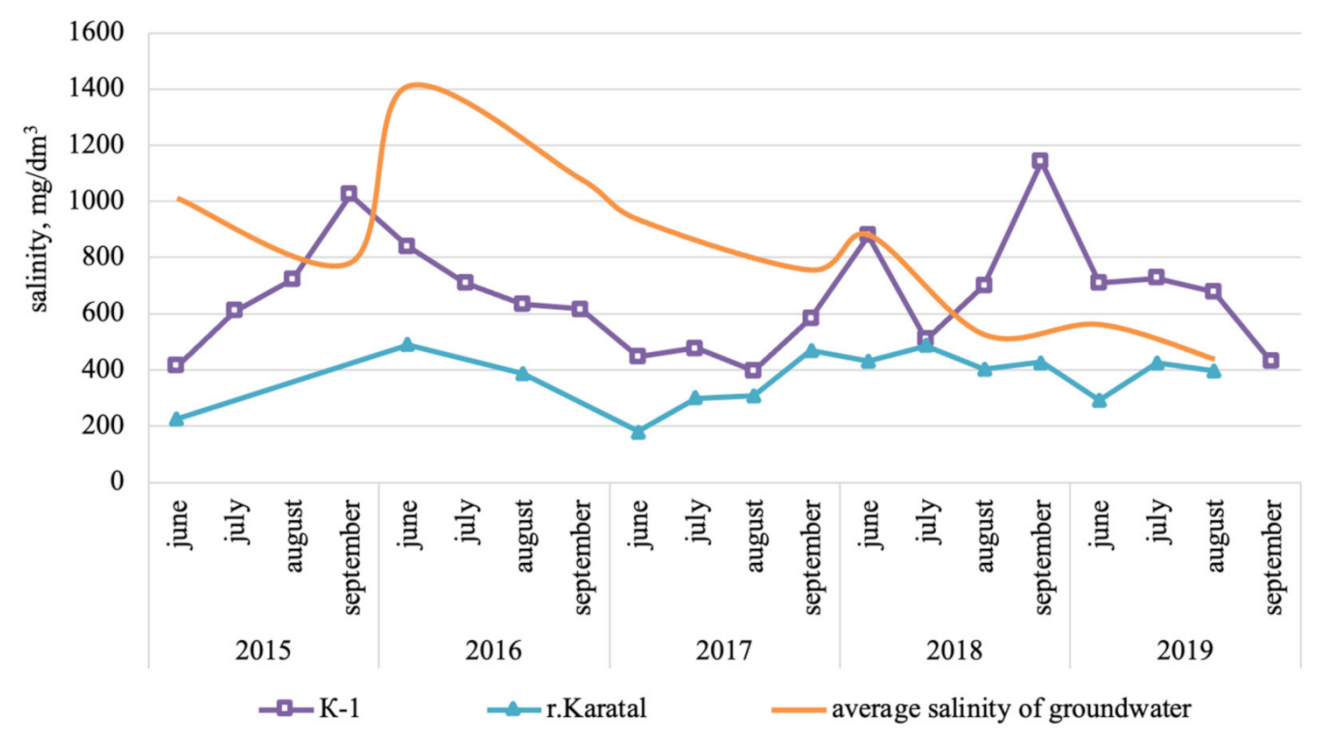

Figure 3. Dynamics of salinity of irrigation and collector-drainage waters and average salinity of GW in the Karatal irrigation massif for 2015-2019, $\mathrm{mg} / \mathrm{dm}^{3}$.

Salt content observations in the Karatal River showed that the salinity of the river water at the beginning of the growing season is low. This effect is related to the amount of precipitation during this period. In the $\mathrm{K}-1$ collector, there is a decrease in the mineralization of collector-drainage waters by the end of the growing season due to the flushing mode during irrigation. 


\subsection{Groundwater Quality and Chemistry}

According to the hydrogeological conditions on the massif, the groundwater regime completely depends on agricultural and water management factors. Groundwater lies at a depth higher than $1.5 \mathrm{~m}$. With the water supply to the fields, there is a widespread rise of the groundwater table, being the highest rate in May and the first days of June. After the end of the irrigation season and the discharge of water from rice checks, there is a decline in the groundwater levels, which continues throughout the inter-vegetation period. In the spring period, the groundwater levels are below $3 \mathrm{~m}$. This indicates favorable conditions for the passage of redox processes in the soils of the aeration zone.

The qualitative characteristics of groundwater in the study area are shown in Figures 4 and 5.

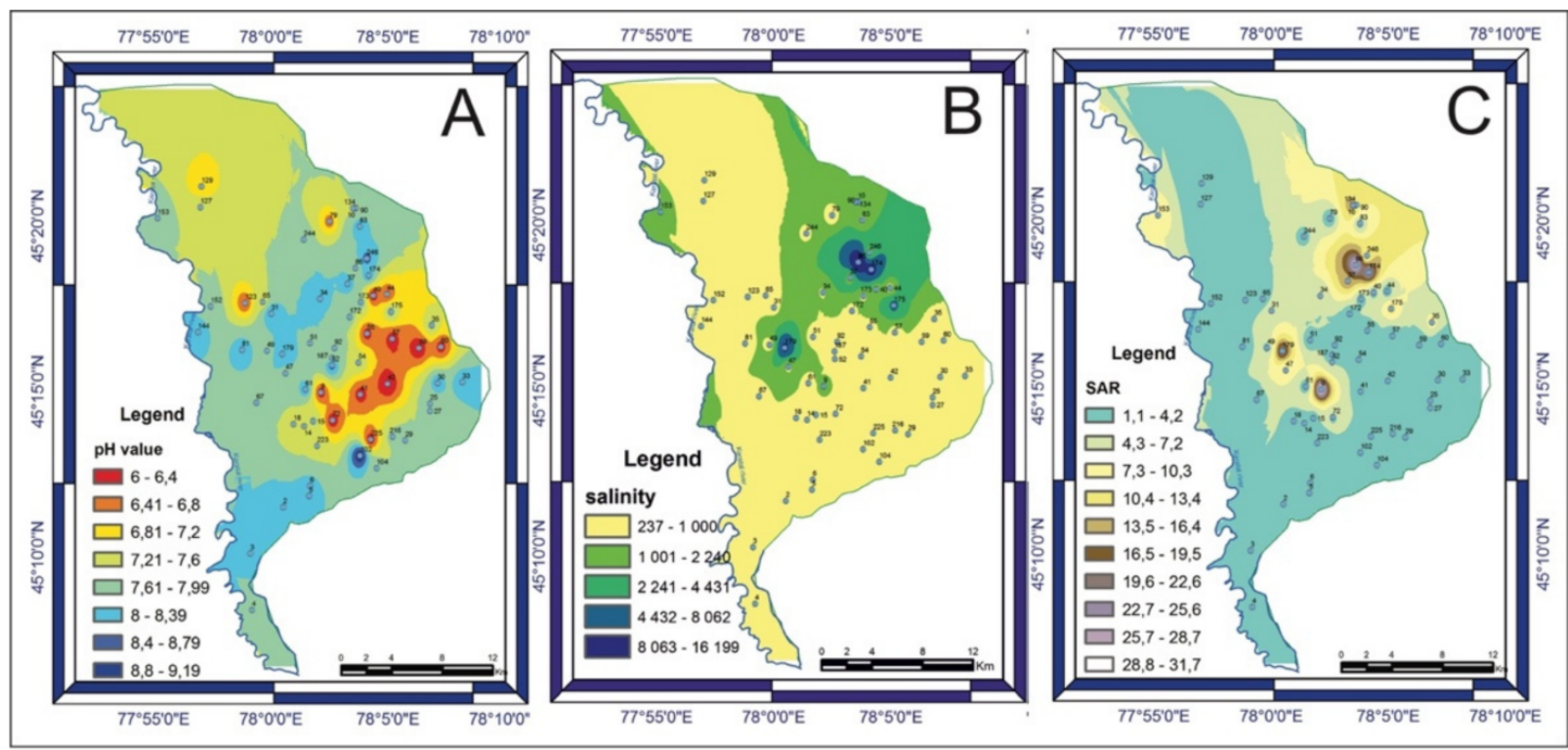

Figure 4. Maps of the spatial distribution of $\mathrm{pH}(\mathbf{A})$, salinity (B), and SAR (C) for the pre-vegetation period.

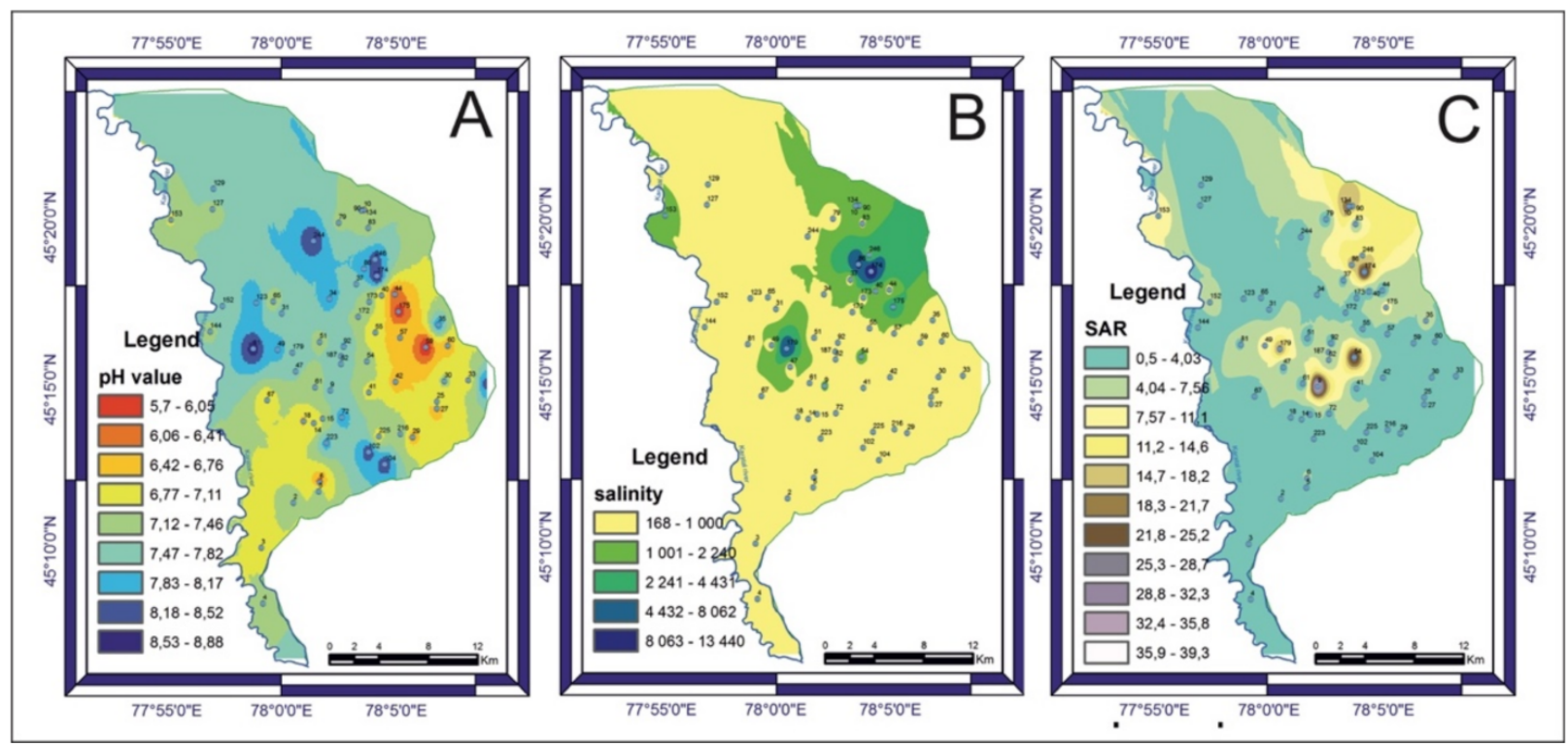

Figure 5. Maps of the spatial distribution of: (A) $-\mathrm{pH},(\mathbf{B})-$ salinity, and (C) - SAR for the postvegetation period. 
The $\mathrm{pH}$ values for the growing season of 2019 ranged from 5.7 to 9.2. In most of the irrigated lands, alkaline groundwater is common, only in the eastern part, slightly acidic water is concentrated (see Figures $4 \mathrm{~A}$ and $5 \mathrm{~A}$ ). At the beginning of the irrigation season, the salinity of groundwater varied from 237 to $1539 \mathrm{mg} / \mathrm{dm}^{3}$ (Figure 4B).

Table 3 presents statistical data of the results of the analysis of groundwater samples (minimum, maximum, average, median, and standard deviation values).

Table 3. Summary statistics for concentrations of chemical components.

\begin{tabular}{|c|c|c|c|c|c|}
\hline \multirow{2}{*}{$\mathrm{mg} / \mathrm{dm}^{3}$} & Min & & & & Standard Deviation \\
\hline & \multicolumn{5}{|c|}{ Numerator (pre-veg.)—Denominator (post-veg.) } \\
\hline \multirow{2}{*}{$\mathrm{CO}_{3}$} & $\underline{0}$ & 5.6 & 0.39 & $\underline{0}$ & 0.9 \\
\hline & $\frac{\overline{0}}{0}$ & $\frac{.0}{2.4}$ & 1.02 & 1.2 & 0.9 \\
\hline \multirow{2}{*}{$\mathrm{HCO}_{3}$} & 1 & 13.4 & 4.09 & 3.1 & 2.69 \\
\hline & 0.2 & 28 & 4.13 & $\frac{0.1}{2.8}$ & 4.22 \\
\hline \multirow{2}{*}{$\mathrm{Cl}$} & $\underline{0.3}$ & 95 & 4.97 & $\underline{0.6}$ & 17.02 \\
\hline & 0.2 & 143.6 & 5.62 & 0.4 & 21.39 \\
\hline \multirow{2}{*}{$\mathrm{SO} 4$} & $\underline{0.5}$ & 167.1 & 8.57 & 1.8 & 25.33 \\
\hline & $\frac{0.0}{0.2}$ & 79 & 4.85 & $\frac{1.0}{0.8}$ & 15.03 \\
\hline \multirow{2}{*}{$\mathrm{Ca}$} & 0.3 & 17.9 & 2.05 & 1.5 & 2.72 \\
\hline & 0.1 & 16.3 & 1.68 & $\frac{1.0}{1.1}$ & 2.55 \\
\hline \multirow{2}{*}{$\mathrm{Mg}$} & 0.3 & 52.2 & 4.28 & $\begin{array}{l}1.5 \\
\end{array}$ & 9.96 \\
\hline & 0.1 & 59.7 & 3.74 & 0.9 & 10.33 \\
\hline \multirow{2}{*}{$\mathrm{Na}+\mathrm{K}$} & $\underline{1.1}$ & 183.1 & 11.68 & 2.75 & 30.67 \\
\hline & 0.6 & 165.3 & 9.41 & 1.9 & 25.85 \\
\hline \multirow{2}{*}{$\mathrm{pH}$} & $\underline{6}$ & 9.2 & 7.57 & 7.8 & 0.84 \\
\hline & $\underline{5.7}$ & 8.9 & 7.33 & 7.25 & 0.67 \\
\hline \multirow{2}{*}{ salinity } & 237 & 16,354 & 1210.4 & 466.5 & 2679.1 \\
\hline & 167 & 13,632 & 986.19 & 340.5 & 2269.8 \\
\hline \multirow{2}{*}{ SAR } & 1.1 & 31.8 & 5.14 & 2.1 & 7.12 \\
\hline & 0.5 & 39.4 & 5.28 & 1.85 & 8.17 \\
\hline
\end{tabular}

The representation of the main components for the pre-and post-vegetation periods is shown in Figures 6 and 7.

The chemical composition of water with minimal salinity is mainly bicarbonate or bicarbonate-sulfate sodium-calcium or sodium, with a salt concentration of more than $500 \mathrm{mg} / \mathrm{dm}^{3}$, the proportion of sulfates increases (see Figures $4 \mathrm{~B}$ and $6 \mathrm{C}$ ). Groundwater with salinity higher than $1000 \mathrm{mg} / \mathrm{dm}^{3}$ has a predominantly bicarbonate sodium chemical composition.

The map of the spatial distribution of the main elements on the pre- (Figure 6) and postvegetation (Figure 7) periods are very similar, which demonstrates the mineralization of groundwater in the massif (Figures 4 and 5). By the end of the growing season, the salinity of groundwater varied from 167 to $1407 \mathrm{mg} / \mathrm{dm}^{3}$ (Figure 5B), with the predominance of bicarbonate, sodium, and calcium ions in the chemical composition. Under rice fields, a decrease in the mineralization of groundwater is characteristic due to dilution and subsequent desalination with irrigation water [17,39].

In fields with rice crops (wells 4, 104, 25, 27, 52, 92, 79) groundwater salinity decreased from $323-1051 \mathrm{mg} / \mathrm{dm}^{3}$ in April to $242-670 \mathrm{mg} / \mathrm{dm}^{3}$ in August due to the flushing regime. This hydrochemical situation persists almost until the end of the irrigation season. After the termination of irrigation, there is a gradual increase in the mineralization of groundwater, due to the fact that in conditions of still high groundwater standing (from 1 to $2 \mathrm{~m}$ ), evaporative processes manifest themselves. Their mineralization increases to $1000 \mathrm{mg} / \mathrm{dm}^{3}$, and the chemical composition is dominated by sulfates and bicarbonates from anions, and sodium comes first from cations, then magnesium. 


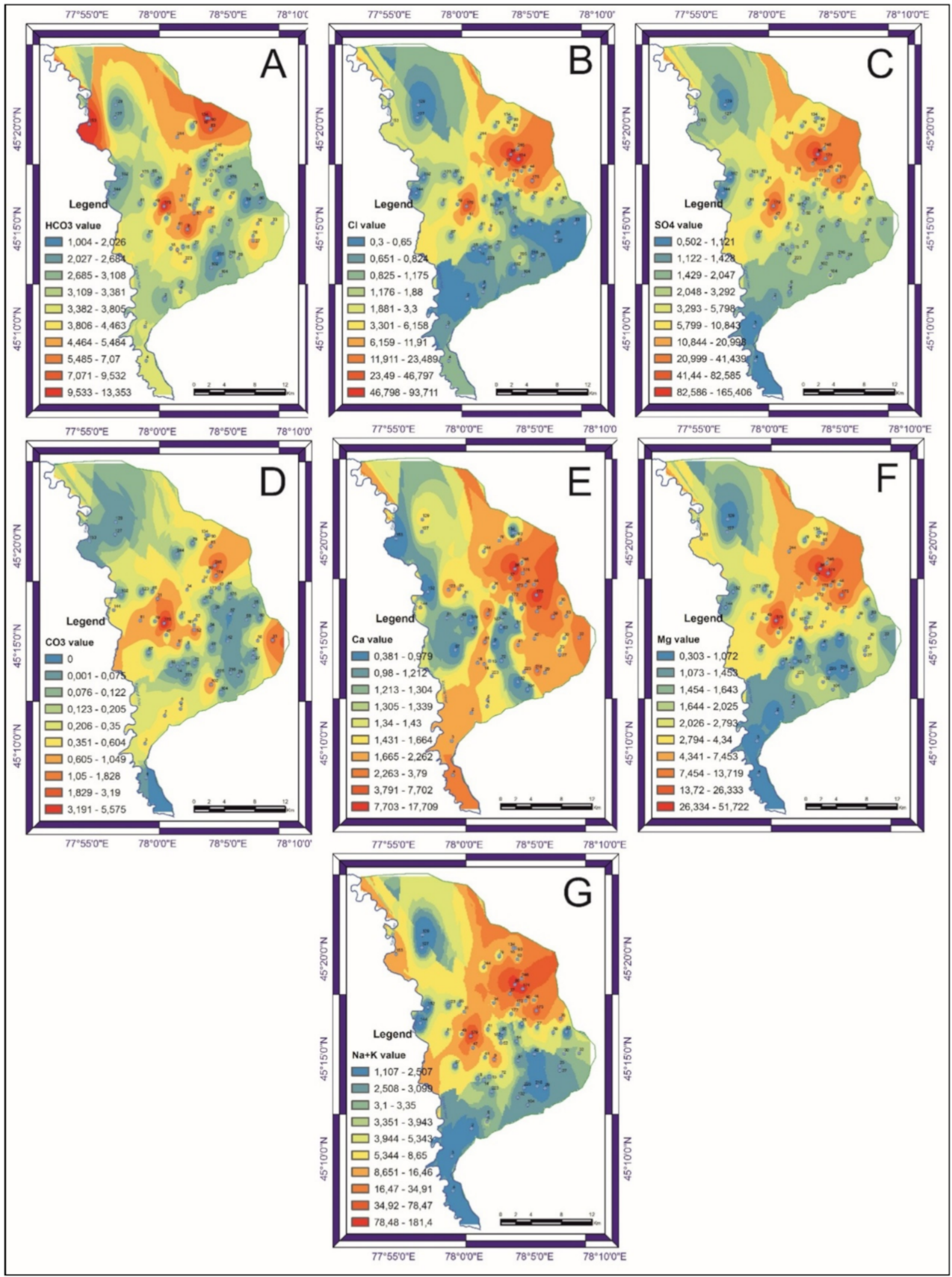

Figure 6. Maps of the spatial distribution of ions for the pre-vegetation period: $(\mathbf{A})-\mathrm{HCO}_{3},(\mathbf{B})-\mathrm{Cl}$, (C) $-\mathrm{SO}_{4},(\mathbf{D})-\mathrm{CO}_{3},(\mathbf{E})-\mathrm{Ca},(\mathbf{F})-\mathrm{Mg},(\mathbf{G})-\mathrm{Na}+\mathrm{K}$. 


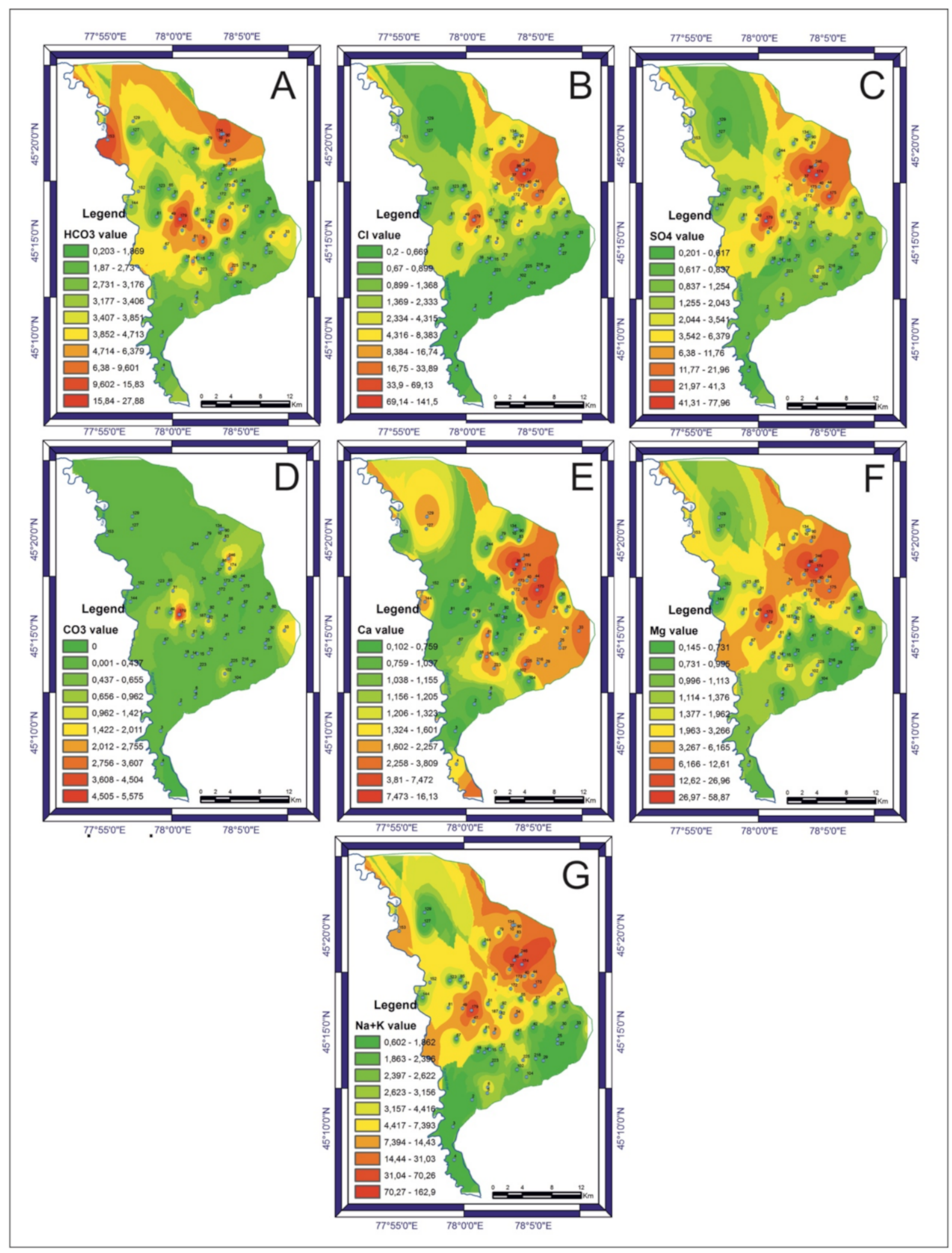

Figure 7. Maps of the spatial distribution of ions for the post-vegetation period: $(\mathbf{A})-\mathrm{HCO}_{3},(\mathbf{B})-\mathrm{Cl}$, (C) $-\mathrm{SO}_{4},(\mathbf{D})-\mathrm{CO}_{3},(\mathbf{E})-\mathrm{Ca},(\mathbf{F})-\mathrm{Mg},(\mathrm{G})-\mathrm{Na}+\mathrm{K}$.

The enrichment of groundwater with sodium cations is explained by the processes of ion exchange with soil solutions of rocks of the aeration zone. According to researchers [17,39], 
when solutions interact with soils, cation exchange most often occurs, as a result of which the content of sodium bicarbonate increases in groundwater. In the fields occupied by dry crops, both the accumulation of salts in the groundwater and their decrease is observed, depending on the degree of salinity of the soil, the drainage of the territory, the amount of water supply as well as the state of the collector and drainage network.

During the growing season, with a sufficiently close occurrence to the earth's surface, the processes of evaporative concentration increase, which leads to a further increase in their mineralization. At the end of the irrigation season, dissolved salts under the influence of climatic and biological factors partially crystallize and move to higher horizons, up to the surface of the earth $[15,39,40]$. For example, in well 225, the salinity of groundwater during the season increased from 314 to $699 \mathrm{mg} / \mathrm{dm}^{3}$, and in well 37, decreased from 1259 to $204 \mathrm{mg} / \mathrm{dm}^{3}$.

High salinization in wells $86,174,175,179$ is caused by the accumulation of salts in groundwaters due to the dissolution of salts of the soil complex. Here, the mineralization in April varied in the range of $5334-16,354 \mathrm{mg} / \mathrm{dm}^{3}$ and $3849-13,632 \mathrm{mg} / \mathrm{dm}^{3}$ in August (see Figures 4B and 5B). The chemical composition is sodium sulfate-chloride or sodiummagnesium chloride-sulfate. According to the survey data, as well as the comparison of the land salinity map, salinization processes are manifested here. According to the salinity patterns in this area, soils with soda and sulfate-soda types are dominated by anions and sodium-by cations. The weighted average salt content in the upper meter thickness reaches $1 \%$ or more.

The state of drainage systems largely determines the nature of the distribution of the salt in the soil profile. Long-term observations in areas occupied by rice crops show unsatisfactory drainage where salts during the irrigation period are washed out to a depth of 50-100 cm. These salts are not removed outside the massif but accumulate in the lower part of the soil profile.

At the end of the irrigation period, an intensive rise of salts in the surface horizons begins. The maximum salt content during this period is located at $0-30 \mathrm{~cm}$ depth. The unsatisfactory condition of the collector and drainage networks does not allow for the removal of drainage water. This leads to an increase in the level of mineralized groundwater, which is aggravated by high evaporation and, subsequently, to an intensive influx of toxic salts into the root layer. High mineralization rates in these wells may also be associated with their location in low terrain areas, where the water exchange process is difficult. In some locations, abnormal results may also be due to technical difficulties and clogged wells (well 86).

Under stabilized groundwater regime conditions, the time to restore the initial state directly depends on the degree of salinity of the soil, its filtration properties, and, to no lesser extent, on the provision of artificial drainage. The return to the original values usually occurs in February-March of the following year [15,39].

Assessment of water quality by the SAR value is mandatory when implementing hydrogeological and reclamation monitoring of irrigated land. The groundwater quality is assessed by determining the salinization risk degree defined by the SAR index. During the growing season, the SAR index in groundwater ranged from 0.5-10.2. In wells with high groundwater salinity, the SAR index varied over the season from 41.3 to 11.9 and from 39.9 to 14.1 . These values indicate a high degree of soil salinization (see Figures $4 \mathrm{C}$ and $5 \mathrm{C}$ ).

There is a close relationship between groundwater mineralization and SAR (correlation coefficient 0.71 ), which is explained by soda salinization.

\subsection{Correlation Analysis of Chemical Parameters}

In this study, a correlation analysis between chemical parameters was carried out to establish the relationships between ions in groundwater. Available data are shown in Table 4. A high positive correlation has been observed between $\mathrm{Cl}^{-}$and $\mathrm{SO}_{4}{ }^{2-}(\mathrm{R}>0.91)$, $\mathrm{Cl}^{-}$and $\mathrm{Mg}^{2+}(0.96), \mathrm{Na}+\mathrm{K}$ and $\mathrm{Cl}^{-}(>0.97), \mathrm{Mg}^{2+}$ and $\mathrm{SO}_{4}{ }^{2-}(>0.94), \mathrm{SO}_{4}{ }^{2-}$ and $\mathrm{Na}+\mathrm{K}$ 
(>0.96), $\mathrm{Mg}^{2+}$ and $\mathrm{Na}+\mathrm{K}(0.97)$. Salinity shows a good correlation with $\mathrm{Cl}^{-}, \mathrm{SO}_{4}{ }^{2-}, \mathrm{Mg}^{+2}$ and $\mathrm{Na}+\mathrm{K}(0.96-0.99)$.

Table 4. Correlation between chemical parameters of groundwater.

\begin{tabular}{|c|c|c|c|c|c|c|c|c|c|}
\hline $\mathrm{mg} / \mathrm{dm}^{3}$ & $\mathrm{CO}_{3}{ }^{2-}$ & $\mathrm{HCO}_{3}{ }^{-}$ & $\mathrm{Cl}^{-}$ & $\mathrm{SO}_{4}^{2-}$ & $\mathrm{Ca}^{+2}$ & $\mathrm{Mg}^{+2}$ & $\mathrm{Na}+\mathrm{K}$ & $\mathrm{pH}$ & Salinity \\
\hline & \multicolumn{9}{|c|}{ Numerator (pre-veg.)—Denominator (post-veg.) } \\
\hline \multirow{2}{*}{$\mathrm{CO}_{3}{ }^{2-}$} & $\underline{1.000}$ & & & & & & & & \\
\hline & $\overline{1.000}$ & & & & & & & & \\
\hline \multirow{2}{*}{$\mathrm{HCO}_{3}{ }^{-}$} & $\underline{0.665}$ & $\underline{1.000}$ & & & & & & & \\
\hline & -0.265 & $\overline{1.000}$ & & & & & & & \\
\hline \multirow{2}{*}{$\mathrm{Cl}^{-}$} & $\underline{0.526}$ & $\underline{0.120}$ & 1.000 & & & & & & \\
\hline & $\overline{0.652}$ & $\overline{0.106}$ & $\overline{1.000}$ & & & & & & \\
\hline \multirow{2}{*}{$\mathrm{SO}_{4}^{2-}$} & $\underline{0.707}$ & $\underline{0.090}$ & $\underline{0.916}$ & $\underline{1.000}$ & & & & & \\
\hline & $\overline{0.590}$ & $\overline{0.214}$ & $\overline{0.951}$ & $\overline{1.000}$ & & & & & \\
\hline \multirow{2}{*}{$\mathrm{Ca}^{2+}$} & -0.287 & $\underline{-0.199}$ & $\underline{0.569}$ & $\underline{0.755}$ & $\underline{1.000}$ & & & & \\
\hline & $\overline{0.123}$ & $\overline{-0.114}$ & 0.430 & 0.583 & $\overline{1.000}$ & & & & \\
\hline \multirow{2}{*}{$\mathrm{Mg}^{2+}$} & $\underline{0.707}$ & $\underline{0.211}$ & $\underline{0.965}$ & $\underline{0.948}$ & $\underline{0.591}$ & $\underline{1.000}$ & & & \\
\hline & $\overline{0.601}$ & $\overline{0.255}$ & $\overline{0.963}$ & $\overline{0.982}$ & $\overline{0.476}$ & $\overline{1.000}$ & & & \\
\hline \multirow{2}{*}{$\mathrm{Na}+\mathrm{K}$} & $\underline{0.657}$ & $\underline{0.190}$ & $\underline{0.970}$ & $\underline{0.977}$ & $\underline{0.638}$ & $\underline{0.974}$ & $\underline{1.000}$ & & \\
\hline & 0.661 & 0.280 & 0.981 & 0.962 & 0.390 & 0.973 & 1.000 & & \\
\hline \multirow{2}{*}{$\mathrm{pH}$} & $\underline{0.259}$ & $\underline{0.164}$ & $\underline{0.136}$ & $\underline{0.123}$ & -0.009 & $\underline{0.179}$ & $\underline{0.148}$ & $\underline{1.000}$ & \\
\hline & 0.738 & -0.006 & $\overline{0.309}$ & $\overline{0.250}$ & $\overline{-0.162}$ & $\overline{0.290}$ & $\overline{0.313}$ & $\overline{1.000}$ & \\
\hline \multirow{2}{*}{ salinity } & $\underline{0.678}$ & $\underline{0.189}$ & $\underline{0.963}$ & $\underline{0.984}$ & $\underline{0.673}$ & $\underline{0.980}$ & $\underline{0.998}$ & $\underline{0.148}$ & $\underline{1.000}$ \\
\hline & $\overline{0.630}$ & $\overline{0.300}$ & $\overline{0.972}$ & $\overline{0.983}$ & $\overline{0.468}$ & $\overline{0.987}$ & $\overline{0.994}$ & $\overline{0.281}$ & $\overline{1.000}$ \\
\hline
\end{tabular}

The $\mathrm{N}+\mathrm{K}$ on the $\mathrm{Cl}$ bivariate plot (Figure $8 \mathrm{a}, \mathrm{a}^{\prime}$ ) is used to demonstrate the origin and amount of dangerous salt. Unusual high values are noted in the northeastern part of the massif. High values of $\mathrm{Na}+\mathrm{K}$ and $\mathrm{Cl}$ have been observed as a result of the dissolution of soil salts during the growing season $[41,42]$. However, the existing irrigation and economic problems in this area do not allow them to be taken outside the massif. Therefore, their ratios change slightly from spring to autumn.
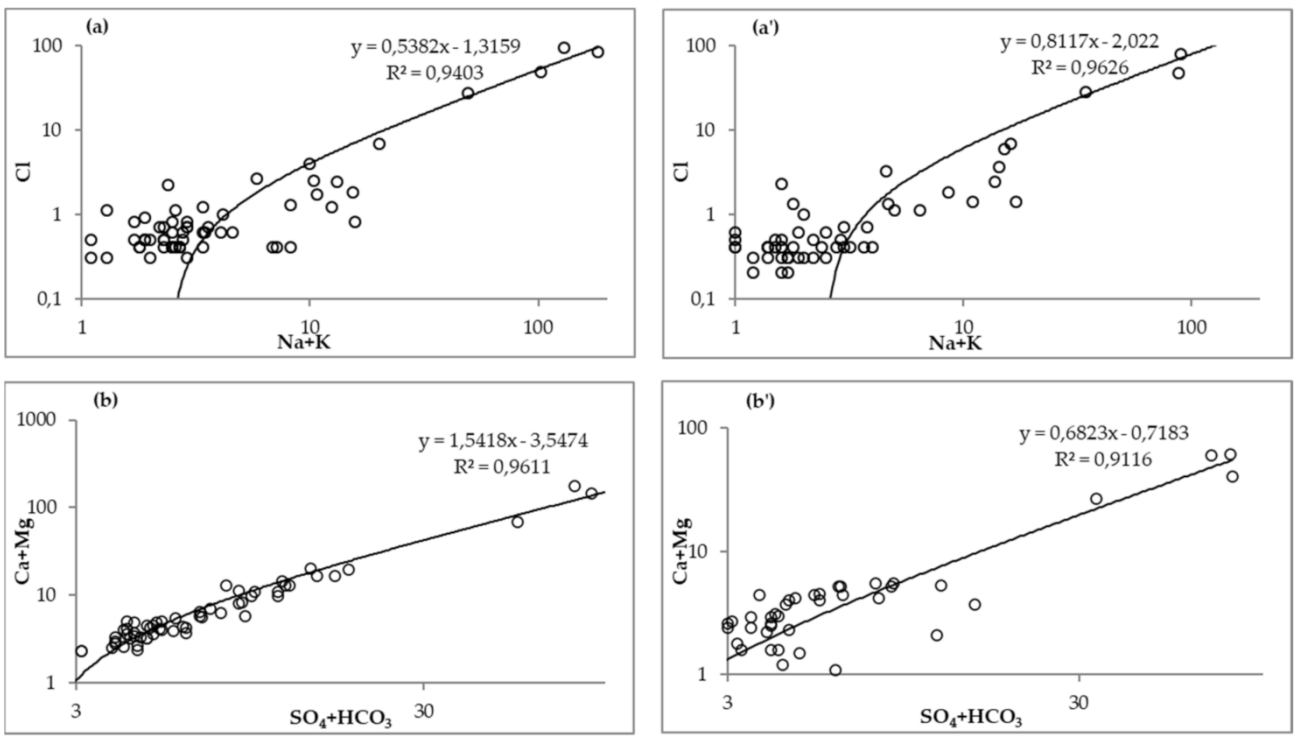

Figure 8. Bivariate plots $\mathrm{Na}+\mathrm{K}$ vs. $\mathrm{Cl}(\mathbf{a})$-pre-vegetation, ( $\left.\mathbf{a}^{\prime}\right)$-post-vegetation $\mathrm{Ca}+\mathrm{Mg}$ vs. $\mathrm{SO}_{4}+\mathrm{HCO}_{3}(\mathbf{b})$ - pre-vegetation, $\left(\mathbf{b}^{\prime}\right)$ - post-vegetation.

The bivariate plot of $\mathrm{Ca}+\mathrm{Mg}$ versus $\mathrm{SO}_{4}+\mathrm{HCO}_{3}$ (Figure $8 \mathrm{~b}, \mathrm{~b}^{\prime}$ ) was used to determine the ion exchange processes, since the carbonate-calcium and the sulfate-calcium system is of particular importance in irrigation conditions. This is due to the fact that the processes of 
dissolution and precipitation of calcium and gypsum carbonates occur just within the limits of mineralization observed in pore waters with natural fluctuations in soil moisture and rocks of the aeration zone and in irrigation groundwater when their reserves change as a result of infiltration of irrigation waters, evaporation, and transpiration [30]. Figure 8 shows the predominance of $\mathrm{Ca}+\mathrm{Mg}$ over $\mathrm{SO}_{4}+\mathrm{HCO}_{3}$ and confirms the process. After infiltration of irrigation waters and dilution of the upper layer of groundwater, greater dissolution of Ca occurs (Figure $8 b^{\prime}$ ), which is the main process responsible for the release of $\mathrm{Ca}^{+2}$.

Figure 9 shows the scatterplots of the distribution of anions and cations by mineralization. Seasonal patterns of changes in the chemical composition of groundwater are observed. At high mineralization ratios, $\mathrm{Cl}^{-}$and $\mathrm{SO}_{4}{ }^{2-}$ predominate in anions while $\mathrm{Na}+\mathrm{K}$ and $\mathrm{Mg}^{+2}$ predominate in cations. However, the values of the four samples differ in all graphs. Further analysis using ArcGIS when building maps was done to explain these anomalies.
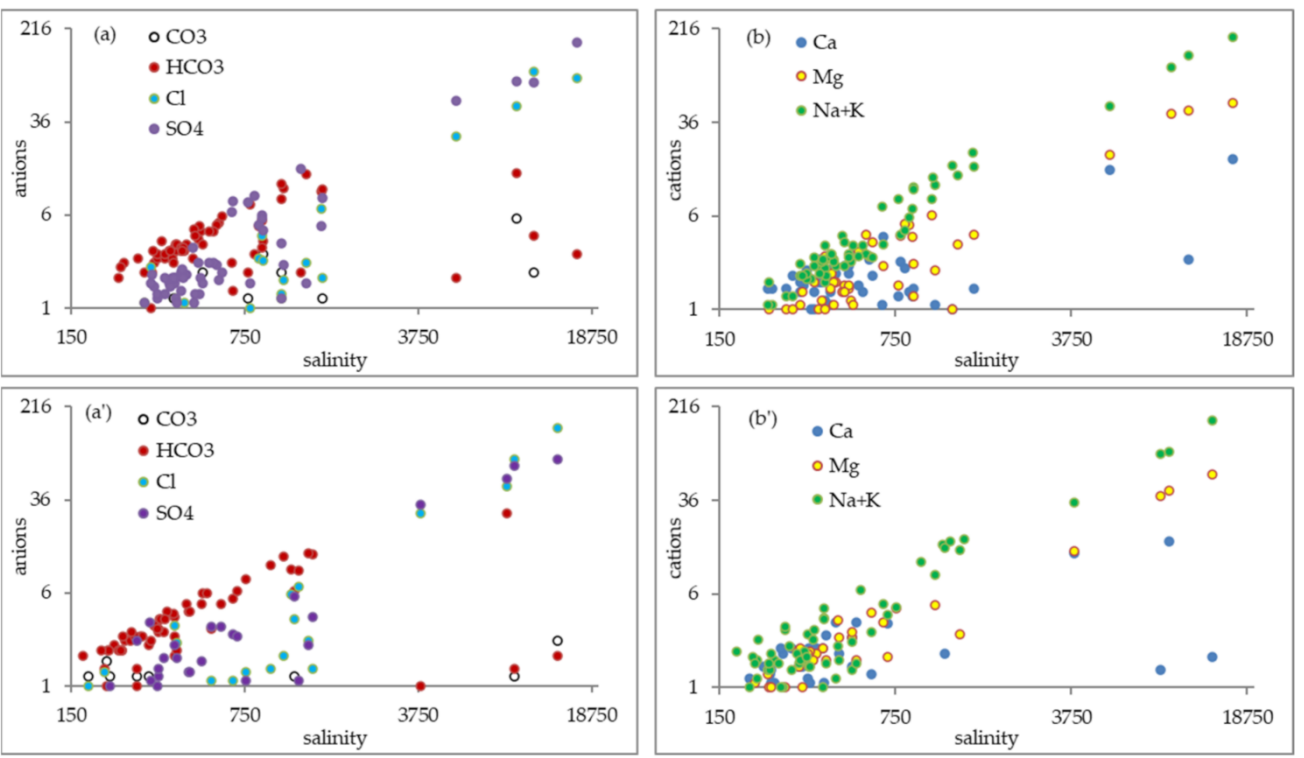

Figure 9. Ion distribution in relation to salinity: anions-(a)—pre-vegetation, cations (b) - prevegetation, anions- $\left(\mathbf{a}^{\prime}\right)$ - post-vegetation, cations- $\left(\mathbf{b}^{\prime}\right)$ - post-vegetation.

Histograms show high covariance values which are due to the fact that ion concentrations (blue stripes on the histograms) at the selected points exceed the average values, so high covariance values are observed in locations where the values in pairs of values are simultaneously higher or lower than the corresponding average values. This effect occurs in two parts of the studied area (Figure 10). Abnormal analysis results have been observed at wells $86,174,175$, and 179 .

The main components analysis indicates the existence of mainly natural processes under the influence of irrigation. The $\mathrm{HCO}_{3}{ }^{-}$and $\mathrm{CO}^{2-}$ anions are formed due to the dissolution of carbonate-containing rocks. The content of the bicarbonate ion often prevails in freshwater (up to $1000 \mathrm{mg} / \mathrm{dm}^{3}$ ).

The amount of sulfate ion increases in weakly and strongly saline groundwater, where it often dominates over other anions. The sulfate ion is the leading one in the formation of the chemical composition of groundwater with mineralization ranging from 1500 to $10,000 \mathrm{mg} / \mathrm{dm}^{3}$. The migration ability of this ion may be limited by a biochemical barrier and the use of chemical ameliorants (sulfate ion, copper sulfate, zinc sulfate). 
(a)

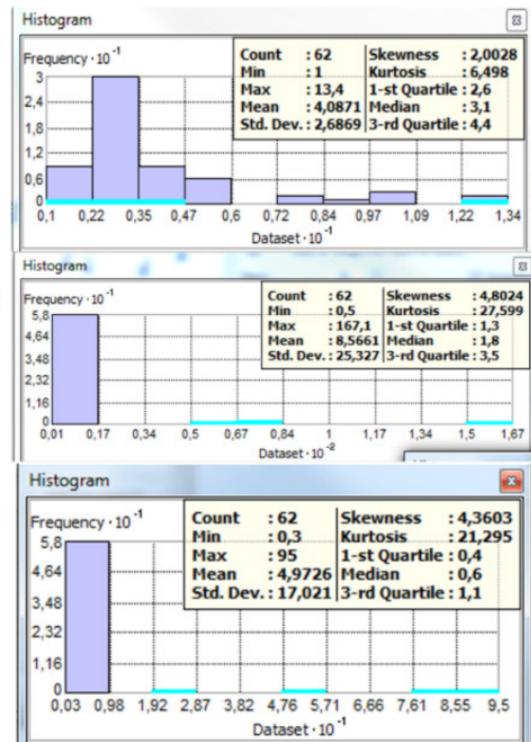

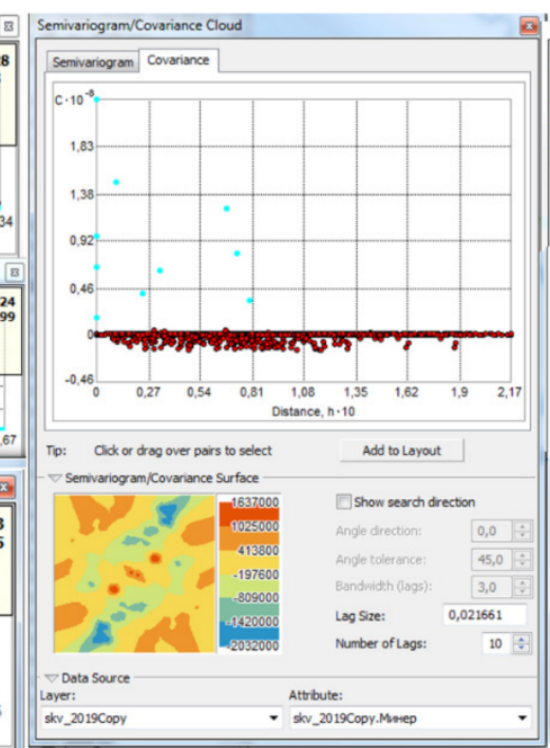

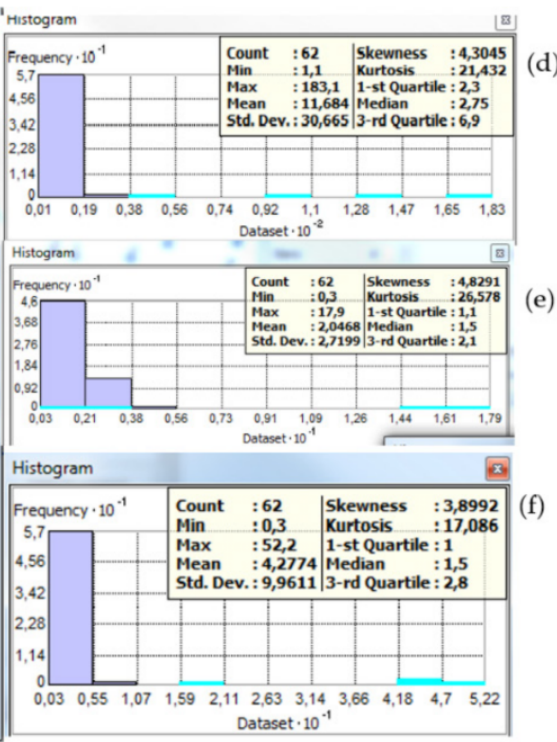

Figure 10. Covariance cloud and attribute histograms: (a) $-\mathrm{HCO}_{3},(\mathbf{b})-\mathrm{SO}_{4},(\mathbf{c})-\mathrm{Cl},(\mathbf{d})-\mathrm{Na}+\mathrm{K}$, (e)-Ca, (f)-Mg.

The chlorine ion content usually does not exceed $20 \mathrm{mg}-\mathrm{eq} \%$. It is most often manifested in the salinity of groundwater from 5000 to $10,000 \mathrm{mg} / \mathrm{dm}^{3}$. Chlorine is the most mobile ion and usually has no biochemical barriers due to the high solubility of its salts.

The content of sodium and potassium in the groundwater composition in most cases was determined jointly. The sodium ion is the main element in the formation of groundwater mineralization on the irrigation array. Most often, it acts as the first element for fresh (up to $\left.1000 \mathrm{mg} / \mathrm{dm}^{3}\right)$ and slightly mineralized $\left(1000-3000 \mathrm{mg} / \mathrm{dm}^{3}\right)$ waters [8]. The sodium ion has practically no solubility barrier due to its good ability to dissolve its salts [41]. It is also retained by plants and in animal organisms.

Calcium is also found in groundwater (15 to $40 \mathrm{mg}-\mathrm{eq} \%$ ). The leading role of this cation is manifested in two ranges of mineralization changes from 250 to $750 \mathrm{mg} / \mathrm{dm}^{3}$ and from 1400 to $3400 \mathrm{mg} / \mathrm{dm}^{3}$. The first range is explained by the calcium carbonate solubility barrier. Its further inhibition within the mineralization range from 700 to $1400 \mathrm{mg} / \mathrm{dm}^{3}$ is associated with its absorption by plants. The second range of mineralization, when the calcium content increases again, is obviously due to the cation exchange between soils and groundwater.

The concentration of magnesium in groundwater ranges from 59 to $83 \mathrm{mg}-\mathrm{eq} \%$. Its predominant role is manifested within the limits of mineralization from 200 to $900 \mathrm{mg} / \mathrm{dm}^{3}$. The content of this cation in water is controlled by a biochemical barrier, since it is well absorbed by plants, participates in photosynthesis, and affects phosphorus and protein metabolism [8].

The areal change in the distribution of fresh and brackish waters from spring to autumn confirms the established chemical regime. The areal distribution of irrigated land by the groundwater salinity degree is shown in Table 5 . Results show that the irrigated area is mainly covered by fresh groundwater with a salinity of up to $1000 \mathrm{mg} / \mathrm{dm}^{3}$. Slightly saline and salty water is distributed over $10-13 \%$ of the area. The area of distribution of slightly saline waters decreased by 414 ha since April, desalinated by diluting them with fresh irrigation water. 
Table 5. Distribution of irrigated land areas by the groundwater mineralization degree in the Karatal massif in 2019.

\begin{tabular}{|c|c|c|c|}
\hline & \multirow{2}{*}{ Area (ha) } & \multicolumn{2}{|c|}{$\begin{array}{c}\text { Water Salinity }\left(\mathrm{mg} / \mathrm{dm}^{3}\right) \\
\text { Numerator (April)—Denominator (September) }\end{array}$} \\
\hline & & $<1000$ & $>1000$ \\
\hline Irrigated area & 11,845 & $\frac{10,240}{10,654}$ & $\frac{1605}{1191}$ \\
\hline
\end{tabular}

The maps of the concentration distribution for each chemical element, for all the tested points, facilitate the visual perception of the existing patterns. Based on the analysis of the actual material of hydrochemical observations shown in Figures 4-7, the existing relationships are noted. When irrigation begins salt ions are redistributed in the groundwater. The bicarbonate ions contents (Figures 6A and 7A) and magnesium (Figures 6F and 7F) increase while sodium (Figures 6G and 7G) and sulfate ion (Figures 6C and 7C) decrease.

\section{Conclusions}

On cultivated lands, irrigation reclamation has an impact on the chemistry of groundwater. As a result of such an impact, complex hydrochemical connections are formed between irrigation waters, soils of the aeration zone, and groundwater. The main factors that control this process are the chemistry of irrigation water, the natural and climatic conditions, and the drainage conditions.

Based on a set of multiple observations of the hydrochemical regime of groundwater in the Karatal massif, a seasonal pattern of changes in the chemical composition of groundwater has been distinguished. For the actual irrigation type of regime in the massif, the change in the ion-salt regime of groundwater directly depends on the ratio of the irrigated and non-irrigated area, the volume of supplied irrigation water, and the drainage capacity of the drainage systems. Depending on the type of crop, the following seasonal patterns are observed in the groundwater regime.

Groundwater mineralization has increased in a relatively small area along the K-4 collector on the PR-35 system and in the lower areas between the K-1 and K-4 reservoirs. The presence of mineralized waters along the collector is facilitated by the fact that the lands of the PR-33-35 system have not been washed in recent years and a significant excess of evaporation over soil wettability contributes to a greater accumulation of salts in waters and soils. The unsatisfactory condition of the drainage network does not compensate for the increased groundwater supply on the P-27 system between the K-1 and K-4 collector and the underground inflow associated with the influence of irrigation channels and groundwater of the surrounding irrigation lands located at higher elevations. This hydrodynamic influence is transmitted to the groundwater that saturates the sand column, from which the water is "squeezed" in the form of ascending currents into the groundwater of the cover loam, which is consumed by evaporation. As a result, salts accumulate in soils and groundwater and mineralization ratios of up to $500-600 \mathrm{mg} / \mathrm{dm}^{3}$ have been observed in the immediate vicinity of the channels. Groundwater is chemically similar to irrigation water (i.e., mainly bicarbonate-sulfate sodium-calcium).

Data obtained from soil samples and irrigation and drainage waters showed that the formation of the hydrochemical regime of groundwater on irrigated lands is influenced by the presence of saline soil-forming rocks, the groundwater levels depth, the volume and quality of irrigation water, and the degree of provision of artificial and natural drainage, as well as by evaporation processes.

Supplementary Materials: The following supporting information can be downloaded at: https: / / www.mdpi.com/article/10.3390/w14030285/s1, Table S1: The available data for each one of the 62 sampling sites. 


\begin{abstract}
Author Contributions: Conceptualization, D.B.B. and V.A.Z.; methodology, D.B.B. and V.A.Z.; software, D.B.B.; validation, D.B.B. and V.A.Z.; formal analysis, J.R.-I. and M.-E.R.-C.; investigation, D.B.B. and V.A.Z.; resources, D.B.B. and V.A.Z.; data curation, D.B.B. and J.R.-I.; writing-original draft preparation, D.B.B., J.R.-I. and M.-E.R.-C.; writing-review and editing, J.R.-I. and M.-E.R.-C.; visualization, J.R.-I. and M.-E.R.-C.; supervision, V.A.Z. and J.E.C.; project administration, D.B.B.; funding acquisition, D.B.B., J.R.-I. and M.-E.R.-C. All authors have read and agreed to the published version of the manuscript.
\end{abstract}

Funding: This research received no external funding.

Informed Consent Statement: Not applicable.

Data Availability Statement: Data used in this study were obtained from field work performed by the Zonal Hydrogeological and Reclamation Center of the Ministry of Agriculture of the Republic of Kazakhstan in 2019.

Conflicts of Interest: The authors declare no conflict of interest.

\title{
References
}

1. Singh, A. Soil salinization management for sustainable development: A review. J. Environ. Manag. 2021, 277, 111383. [CrossRef]

2. Cuevas, J.; Daliakopoulos, I.N.; del Moral, F.; Hueso, J.J.; Tsanis, I.K. A review of soil-improving cropping systems for soil salinization. Agronomy 2019, 9, 295. [CrossRef]

3. Daliakopoulos, I.N.; Tsanis, I.K.; Koutroulis, A.; Kourgialas, M.N.; Varouchakis, A.E.; Karatzas, G.P.; Ritsema, C.J. The threat of soil salinity: A European scale review. Sci. Total Environ. 2016, 573, 727-739. [CrossRef] [PubMed]

4. Mao, W.; Zhu, Y.; Wu, J.; Ye, M.; Yang, J. Evaluation of effects of limited irrigation on regional-scale water movement and salt accumulation in arid agricultural areas. Agric. Water Manag. 2022, 262, 107398. [CrossRef]

5. Zaporozec, A. Graphical Interpretation of Water-Quality Data. Groundwater 1972, 10, 32-43. [CrossRef]

6. Katz, D.M. The Effect of Irrigation on Groundwater; Kolos: Moscow, Russia, 1976.

7. Duyunov, I.K. Land Reclamation in the Conditions of Groundwater Pressure Supply; Kolos: Moscow, Russia, 1978.

8. Gorev, L.N.; Peleshenko, V.I. Meliorative Hydrochemistry; Vishchashkola: Kiev, Ukraine, 1984.

9. Ayers, R.S.; Westcot, D.W. Water Quality for Agriculture. In FAO Irrigation and Drainage Paper; FAO: Rome, Italy, 1985; Volume 29, p. 176.

10. Rabemanana, V.; Violette, S.; de Marsily, G.; Robain, H.; Deffontaines, B.; Andrieux, P.; Bensimon, M.; Parriaux, A. Origin of the high variability of water mineral content in the bedrock aquifers of Southern Madagascar. J. Hydrol. 2005, 310, 143-156. [CrossRef]

11. Scanlon, B.R.; Jolly, I.; Sophocleous, M.; Zhang, L. Global impacts of conversions from natural to agricultural ecosystems on water resources: Quantity versus quality. Water Resour. Res. 2007, 43. [CrossRef]

12. Rotiroti, M.; Bonomi, T.; Sacchi, E.; McArthur, J.M.; Stefania, G.A.; Zanotti, C.; Taviani, S.; Patelli, M.; Nava, V.; Soler, V.; et al. The effects of irrigation on groundwater quality and quantity in a human-modified hydro-system: The Oglio River basin, Po plain, northern Italy. Sci. Total Environ. 2019, 672, 342-356. [CrossRef]

13. Jia, H.; Qian, H.; Zheng, L.; Feng, W.; Wang, H.; Gao, Y. Alterations to groundwater chemistry due to modern water transfer for irrigation over decades. Sci. Total Environ. 2020, 717, 13170. [CrossRef]

14. Shomar, B. Geochemistry of soil and groundwater in arid regions: Qatar as a case study. Groundw. Sustain. Dev. 2015, 1, 33-40. [CrossRef]

15. Khodjibaev, N.N. Hydrogeological and Meliorative Zoning; Fan Publishing: Tashkent, Uzbekistan, $1975 ;$ p. 143.

16. Katz, D.M.; Shestakov, V.M. Meliorative Hydrogeology; MSU: Moscow, Russia, 1981; p. 296.

17. Rau, A.; Bakirov, A.; Anuarbek, K.; Kudasheva, J. Geochemistry of water in rice irrigation systems Akdala. News Natl. Acad. Sci. Repub. Kazakhstan 2019, 5, 74-81. [CrossRef]

18. Tewabe, D.; Dessie, M.; Asmamaw, D.K.; Tamiru, E.; Adgo, E.; Nyssen, J.; Walraevens, K.; Cornelis, W.M. Comparative analysis of groundwater conditions on rain-fed and irrigated agriculture in the upper Blue Nile basin, Ethiopia. J. Hydrol. Reg. Stud. 2021, 37, 100916. [CrossRef]

19. Moharir, K.; Pande, C. Spatial analysis of groundwater quality mapping in hard rock area in the Akola and Buldhana districts of Maharashtra, India. Appl. Water Sci. 2018, 8, 106. [CrossRef]

20. Boyd, C.E. Water Quality, an Introduction; Springer International Publishing: Cham, Switzerland, 2000; p. 323.

21. Schoeller, H. Geochemistry of Groundwater: An International Guide for Research and Practice; UNESCO: India, 1967; Chapter 15; pp. 1-18.

22. Hale, B.; Evans, L.; Lambert, R. Effects of cement or lime on $\mathrm{Cd}, \mathrm{Co}, \mathrm{Cu}, \mathrm{Ni}, \mathrm{Pb}, \mathrm{Sb}$ and $\mathrm{Zn}$ mobility in field-contaminated and aged soils. J. Hazard. Mater. 2012, 199-200, 119-127. [CrossRef] [PubMed]

23. Bolan, N.S.; Rowarth, J.; Mora, M.L.L.; Adriano, D.; Curtin, D. Biological transformation and bioavailability of nutrient elements in acid soils as affected by liming. Dev. Soil Sci. 2008, 32, 413-446. [CrossRef]

24. Beecher, H.G. Effect of saline water on rise and soil properties in the Murrumbidgee Valley. Austral. J. Exp. Agr. 1991, 6, 819. [CrossRef] 
25. Asch, F.; Dingkuhn, M.; Dorffling, K. Salinity increases $\mathrm{CO}_{2}$ assimilation but reduce growth in field-grown irrigated rice. Plant Soil 2000, 218, 1-10. [CrossRef]

26. Kitamura, Y.; Yano, T.; Yasuda, S.; Oba, T. Water and salt behavior in an irrigation block under rice-based cropping system in Central Asia-Research on water management to prevent secondary salinization in Arid Land (II). Trans. Jpn. Soc. Irri. Drain. Reclam. Eng. 2000, 206, 47-56. [CrossRef]

27. Asch, F.; Wopereis, M.S.C. Responses of field-grown irrigated rice cultivars to varying levels of floodwater salinity under semi-arid conditions. Field Crops Res. 2001, 70, 127-137. [CrossRef]

28. Rau, A.G. Rice production on saline lands in the Syrdarya basin. In Proceedings of the Water Resources of Central Asia and Their Use Conference Proceedings, Almaty, Kazakhstan, 22-23 September 2016.

29. Chen, L.; Feng, Q. Geostatistical analysis of temporal and spatial variations in groundwater levels and quality in the Minqin oasis, Northwest China. Env. Earth Sci. 2013, 70, 1367-1378. [CrossRef]

30. Shakibayev, I.; Barmakova, D.; Yerikuly, Z.; Rau, G.; Kadasheva, Z.; Begmatov, I. Methodology for creating a geoinformationanalytical system to monitor irrigated lands in the south-east of Kazakhstan. Proc. InterCarto. InterGIS Conf. 2020, 26, 286-293. [CrossRef]

31. Piper, A.M. A graphic procedure in geochemical interpretation of water analysis. Trans. Am. Geophys. Union 1944, 25, 914-928. [CrossRef]

32. Fritch, T.G.; McKnigth, C.L.; Yelderman, J.C.; Dworkin, S.I.; Arnold, J.G. A predictive modeling approach to assessing the groundwater pollution susceptibility of the Paluxy Aquifer, Central Texas, using a Geographic Information System. Environ. Geol. 2000, 39, 1063-1069. [CrossRef]

33. Böhlke, J.K. Groundwater recharge and agricultural contamination. Hydrogeol. J. 2000, 10, 153-179. [CrossRef]

34. Tiwari, K.; Goyal, R.; Sarkar, A. GIS-based spatial distribution of groundwater quality and regional suitability evaluation for drinking water. Environ. Proc. 2007, 4, 645-662. [CrossRef]

35. Salikova, N.S.; Rodrigo-Ilarri, J.; Alimova, K.K.; Rodrigo-Clavero, M.E. Analysis of the Water Quality of the Ishim River within the Akmola Region (Kazakhstan) Using Hydrochemical Indicators. Water 2021, 13, 1243. [CrossRef]

36. Honarbakhsh, A.; Azma, A.; Nikseresht, F.; Mousazadeh, M.; Eftekhari, M.; Ostovari, Y. Hydro-chemical assessment and GIS-mapping of groundwater quality parameters in semi-arid regions. J. Water Supply Res. Technol.-Aqua 2019, 68, 509-522. [CrossRef]

37. The Rules of State Conduct Monitoring and Evaluation of Ameliorative Condition of Irrigated Lands in the Republic of Kazakhstan and Information Data Bank on Reclamation of the land for Agricultural Purposes. Approved by the Ministry of Agriculture of the Republic of Kazakhstan on 25 July 2016. No. 330. Available online: https:/ / adilet.zan.kz/rus/docs/V1600014227 (accessed on 16 January 2022).

38. Ndoye, S.; Fontaine, C.; Becaye Gaye, C.; Razack, M. Groundwater quality and suitability for different uses in the Saloum Area of Senegal. Water 2018, 10, 1837. [CrossRef]

39. Averyanov, S.F. Filtration from Channels and Its Influence on the Groundwater Regime//The Influence of irrigation Systems on the Groundwater Regime; USSR: Kolos, Moscow, 1982.

40. Katz, D.M. The Groundwater Regime of Irrigated Areas and Its Regulation; H UTCHINSON/FAO/UNESC: Moscow, Russia, 1963; p. 367.

41. Pulido-Bosch, A.; Rigol-Sánchez, J.P.; Vallejos, Á.; Andreu, J.M.; Cerón, J.C.; Molina-Sánchez, L.; Sola, F. Impacts of agricultural irrigation on groundwater salinity. Environ. Earth Sci. 2018, 77, 197. [CrossRef]

42. Suárez, D.L. Impact of Agricultural Practices on Groundwater Salinity. Agric. Ecosyst. Environ. 1989, 26, 215-227. [CrossRef] 